\title{
Efek hidrogel getah jarak cina (Jatropha multifida Linn.) berbasis karagenan kappa dan karagenan iota terhadap penyembuhan luka tikus wistar jantan
}

\author{
Fetri Lestari, Amila Gadri, Gita Cahya Eka Darma, Rikka Kartika \\ ${ }^{1}$ Program Studi Farmasi, FMIPA, Universitas Islam Bandung \\ Jl. Ranggagading No 8 Bandung
}

Submitted: 28-04-2016

Reviewed: 14-05-2016

Accepted: 03-11-2016

\begin{abstract}
ABSTRAK
Getah jarak cina (Jatropha multifida Linn.) diketahui memiliki aktivitas dalam penyembuhan luka. Telah dikembangkan sediaan hidrogel mengandung 3\% getah jarak cina dengan variasi basis polimer karagenan kappa dan karagenan iota yang memenuhi karakteristik sediaan yang baik. Penelitian ini bertujuan untuk mengetahui efek penyembuhan luka dari kedua sediaan hidrogel tersebut pada tikus Wistar. Pengujian dilakukan terhadap lima kelompok tikus yang diberi luka berdiameter $1,5 \mathrm{~cm}$ di area punggung, terdiri dari kelompok kontrol, dua kelompok uji yang masing-masing diberi sediaan hidrogel getah jarak cina berbasis 2\% karagenan kappa (kelompok hidrogel-kappa) dan sediaan hidrogel getah jarak cina berbasis $2 \%$ karagenan iota (kelompok hidrogel-iota), serta dua kelompok yang masingmasing diberi basis hidrogel yang berbeda sesuai tipe sediaan uji. Parameter penyembuhan luka mencakup waktu kering luka, waktu terbentuk keropeng, dan perubahan diameter luka. Hasil menunjukkan kelompok hidrogel-kappa mengalami penyembuhan luka paling cepat dibandingkan kelompok kontrol secara signifikan $(\mathrm{p}<0,05)$ dan dibandingkan kelompok hidrogel-iota berdasarkan waktu kering luka (16,6 $\pm 2,2$ jam) dan waktu terbentuk keropeng $(92,6 \pm 2,2$ jam). Kelompok hidrogelkappa juga menunjukkan perubahan diameter luka paling baik pada hari ke-21 yaitu mengecil hingga $0,02 \pm 0,03 \mathrm{~cm}$ dibandingkan kelompok kontrol dan kelompok hidrogel-iota. Sehingga disimpulkan sediaan hidrogel yang mengandung 3\% getah jarak cina dan berbasis polimer $2 \%$ karagenan kappa memberikan efek lebih baik dalam mempercepat penyembuhan luka dibandingkan sediaan berbasis polimer karagenan iota pada penelitian ini.
\end{abstract}

Kata kunci : Getah jarak cina (Jatropha multifida Linn.), hidrogel, kappa karagenan, iota karagenan, penyembuhan luka

\begin{abstract}
Jatropha multifida Linn. latex has been reported in many study for its activities to treats wound. Preparation of hydrogels containing 3\% of Jatropha multifida Linn. latex with variety of base polymers kappa carrageenan and iota carrageenan was conducted and met good characteristics. This study aimed to evaluate effect of both hydrogels to promote wound healing in Wistar rats. Tests carried out on five groups of rats with $1.5 \mathrm{~cm}$ diameter of wound in the back area, consisting of a control group, two test groups were each treated by $2 \%$ kappa carrageenan-based hydrogel (kappa-hydrogel group) and 2\% iota carrageenan-based hydrogel (iota-hydrogel group) of the latex, and two groups were each given a different hydrogel base according to type of hydrogel tested. Effect on wound healing was assessed by parameters including wound drying period, scab forming period, and the change in diameter of the wound. Results show kappa-hydrogel group achieve the most rapid wound healing compare to the control group significantly $(\mathrm{p}<0,05)$ and the iota-hydrogel group on wound drying period (16.6 \pm 2.2 hours) and scab forming period ( $92.6 \pm 2.2$ hours).
\end{abstract}

Penulis korespondesi:

Fetri Lestari

Program Studi Farmasi, FMIPA, Universitas Islam Bandung

J1. Ranggagading No 8 Bandung

Email: fetrilestari@gmail.com 
Kappa-hydrogel group also show best changes in diameter of the wound at day 21 which is reduced to $0.02 \pm 0.03 \mathrm{~cm}$, compare to the control group and iota-hydrogel group. As a conclusion, the $2 \%$ kappa carrageenan-based hydrogel containing 3\% of Jatropha multifida Linn. latex produce better effect to promote wound healing than iota carrageenan-based hydrogel in this study.

Keywords: Jatropha multifida Linn. latex, hydrogel, kappa carrageenan, iota carrageenan, wound healing

\section{PENDAHULUAN}

Getah jarak cina (Jatropha multifida Linn.) telah diketahui memberikan efek mempersingkat waktu perdarahan pada luka sayatan. Aktivitas hemostatik ini disebabkan adanya kandungan tanin dan flavonoid dalam getah (Dougnon et al., 2012). Pada penelitian Syarfati dan Damhoeri (2011), getah jarak cina berpotensi sama dengan povidon iodin dalam lama waktu terbentuk keropeng pada luka baru, lama pengelupasan keropeng dan penyembuhan luka tidak berbeda nyata, permukaan luka yang telah sembuh dengan pengolesan getah jarak cina terbentuk sempurna seperti semula. Pada penelitian Aiyelaagbe et al. (2008), menunjukkan bahwa jarak cina memiliki aktivitas sebagai anti mikroba.

Kebanyakan tumbuhan bila digunakan secara langsung atau sebagai ekstrak kasar, mungkin mengandung mikroorganisme sehingga potensial sebagai sumber infeksi (Boateng et al., 2008). Untuk meningkatkan efektivitas getah jarak cina dalam penyembuhan luka, telah dikembangkan formulasi sediaan topikal. Pada penelitian sebelumnya, dikembangkan formulasi sediaan gel dan salep mengandung $1 \%$ dan 3\% getah jarak cina menghasilkan gel dan salep yang memenuhi syarat secara farmasetika dan memberikan efek yang lebih baik pada penyembuhan luka pada mencit dibandingkan kontrol, terutama penyembuhan luka tercepat dicapai oleh gel mengandung 3\% getah (Amila et al., 2015). Tahap berikutnya, dikembangkan formulasi sediaan pembalut luka dari getah jarak cina yang termasuk kategori modern dressing yaitu berupa hidrogel.

Hidrogel merupakan jaringan rantai polimer tiga dimensi dengan ikatan silang yang memiliki kapasitas mengembang (swelling) dengan menyerap air atau cairan biologis dan tidak larut serta tetap mempertahankan struktur tiga dimensinya (Omidian et al., 2013). Kemampuan menyerap air disebabkan terikatnya gugus hidrofilik kepada rantai polimerik. Resistensi terhadap disolusi timbul akibat adanya ikatan silang antar rantai polimer (Ahmed, 2015). Hidrogel dapat digunakan sebagai gel amorf atau sebagai lembaran atau film yang elastis dan padat. Hidrogel film dapat digunakan untuk pembalut luka primer maupun sekunder (Boateng et al., 2012).

Polimer yang dipilih sebagai basis hidrogel getah jarak cina adalah polimer alam berupa karagenan kappa dan karagenan iota. Karagenan kappa dan karagenan iota berasal dari spesies rhodophyta yang berbeda (Distantina et al., 2010). Hidrogel dari polimer alam secara umum non toksik dan biodegradable (Ahmed, 2015). Formulasi hidrogel dengan basis karagenan iota 2\% memberikan karakteristik yang baik berdasarkan parameter uji organoleptik, kemampuan mengembang, dan fraksi gel (Gadri et al., 2014). Sediaan hidrogel getah jarak cina berbasis $2 \%$ karagenan kappa menunjukkan karakteristik kemampuan mengembang dan fraksi gel yang baik (Gadri et al., 2015).

Berdasarkan hasil dari pengembangan formulasi sediaan di atas, penelitian ini bertujuan untuk mengetahui dan membandingkan efek penyembuhan luka hidrogel getah jarak cina berbasis karagenan kappa dan karagenan iota pada tikus Wistar.

\section{METODE PENELITIAN}

Alat dan Bahan

Jarak cina diperoleh dari Manoko, Lembang. Getah diperoleh melalui penyadapan dengan menyayat batang tanaman dan kemudian dibuat serbuk getah dengan alat freeze dryer. Sediaan hidrogel mengandung 3\% getah jarak cina dibuat dalam dua formula basis mengandung 2\% karagenan kappa (formula 1) atau karagenan iota (formula 2), kalium klorida (formula 1) atau kalsium klorida (formula 2), PVP, PEG 400, propilenglikol, gliserin, agar, nipagin dan nipasol dalam kedua formula. Hidrogel yang dihasilkan membentuk lapisan film (Gambar 1). 


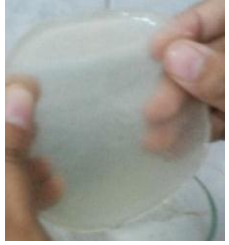

(a)

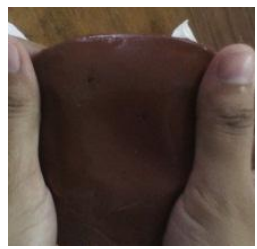

(b)

Gambar 1. Film hidrogel berbasis karagenan

(a) tanpa getah jarak cina, (b) mengandung getah jarak cina

Uji efek dilakukan terhadap 5 kelompok tikus Wistar jantan masing-masing terdiri dari 5 ekor dengan bobot 150-200 gram, usia 2-3 bulan.

\section{Jalannya Penelitian Pengelompokan hewan}

Tikus sebanyak 25 ekor dibagi menjadi 5 kelompok masing-masing terdiri dari 5 ekor yaitu kelompok kontrol; kelompok yang diberi sediaan hidrogel getah jarak cina dengan basis polimer karagenan kappa (kelompok hidrogel-kappa); kelompok yang diberi basis hidrogel dengan polimer karagenan kappa (kelompok basis hidrogel-kappa); kelompok yang diberi sediaan hidrogel getah jarak cina dengan basis polimer karagenan iota (kelompok hidrogel-iota); dan kelompok yang diberi basis hidrogel dengan polimer karagenan iota (kelompok basis hidrogel-iota).

\section{Induksi luka}

Tikus dianestesi dengan ketamin 70mg/Kg BB secara intraperitoneal, kemudian diletakkan di atas bak bedah dengan posisi telungkup dan keempat kaki diikat. Rambut di sekitar punggung bagian tengah tikus dicukur, kemudian dibersihkan dengan kapas yang dibasahi alkohol 70\%. Luka dibuat berbentuk lingkaran dengan diameter $1,5 \mathrm{~cm}$, dengan menggunting kulit pada bagian yang telah ditandai sampai bagian dermis beserta jaringan ikat dibawahnya.

\section{Uji aktivitas penyembuhan luka}

Masing masing kelompok tikus diaplikasikan sediaan uji yang sesuai pada lingkaran luka dengan ketebalan pengolesan yang sama dan kemudian dibalut dengan kasa steril untuk menghindari kontaminasi dan agar film hidrogel tidak terlepas akibat pergerakan tikus. Pemberian sediaan dilakukan setiap dua kali sehari, pada interval waktu yang sama sampai luka sembuh.

Pengamatan proses penyembuhan luka dilakukan tiga kali sehari pada interval waktu yang sama. Parameter untuk menentukan efek penyembuhan luka meliputi waktu kering luka, waktu terbentuk keropeng dan perubahan diameter luka pada hari ke-21.

\section{Analisis Data}

Data dianalisa secara statistik non parametrik dengan menggunakan uji Mann-Whitney $(\alpha=0,05)$ untuk mengetahui signifikansi perbedaan antara kelompok hidrogel- kappa dan kelompok hidrogel-iota) dengan kelompok kontrol.

\section{HASIL DAN PEMBAHASAN}

Waktu kering luka pada kelompok hidrogel-kappa dan kelompok hidrogel-iota lebih cepat dibandingkan waktu kering luka kelompok basis dan juga lebih cepat dibandingkan kontrol (44,1 jam). Waktu pengeringan luka tercepat dicapai oleh sediaan hidrogel-kappa dengan rata-rata 16,6 jam. Efek pengeringan luka oleh kelompok hidrogel-kappa dan hidrogel-iota signifikan secara statistik dibandingkan kontrol $(\mathrm{p}=0,002 ; 0,001)$. Efek yang diberikan hidrogel-kappa tidak berbeda bermakna dibandingkan hidrogel-iota dengan nilai $\mathrm{p}=0,324$. Pengamatan waktu kering luka tercantum pada Tabel I.

Hasil ini menunjukkan adanya efek dari serbuk getah jarak cina dalam sediaan hidrogel terhadap proses penyembuhan luka, melebihi pengaruh yang diberikan basis. Tanin yang terdapat dalam getah jarak cina dapat menimbulkan efek vasokontriksi pembuluh darah kapiler (Syarfati dan Damhoeri, 2011). Film hidrogel dapat mengabsorbsi dan menahan sejumlah volume air ketika kontak dengan luka basah (Boateng et al., 2008). 
Tabel I. Waktu kering luka tikus setelah pemberian sediaan

\begin{tabular}{lcc}
\hline Kelompok & $\begin{array}{c}\text { Rata-rata Waktu Kering Luka } \\
\text { (jam) } \pm \text { SD }\end{array}$ & $\mathbf{p}^{*}$ \\
\hline Kontrol & $44,1 \pm 4,3$ & - \\
Basis Hidrogel- Kappa & $24,2 \pm 1,8$ & - \\
Sediaan Hidrogel-Kappa & $16,6 \pm 2,2$ & 0,002 \\
Basis Hidrogel-Iota & $24,2 \pm 1,8$ & - \\
Sediaan Hidrogel-Iota & $18,8 \pm 1,8$ & 0,001 \\
*p pignifikansi perbedaan waktu kering luka kelompok uji dibandingkan kelompok kontrol \\
\multicolumn{2}{l}{ berdasarkan uji statistik Mann-Whitney }
\end{tabular}

Fase inflamasi terjadi bersamaan dengan hemostasis, mulai dari beberapa menit sampai 24 jam setelah terbentuk luka dan berakhir sampai sekitar 3 hari, melibatkan respon selular dan vaskular. Pelepasan eksudat yang kaya protein kepada luka menyebabkan vasodilatasi melalui pelepasan histamin dan serotonin, sehingga memberi jalan bagi makrofag untuk menuju luka dan memfagosit jaringan nekrotik (Boateng et al., 2008). Perbaikan matriks jaringan ikat diatur oleh sel-sel radang dengan melepaskan sitokin yang dikenal sebagai faktor pertumbuhan (Schwartz, 2000).

Jaringan nekrotik yang keras diuraikan oleh aktivitas enzimatik sehingga menghasilkan massa cairan yang berwarna kekuningan. Lingkungan yang kering mencegah aktivitas proteolitik tersebut sebaliknya eksudat berlebih akan menghambat proliferasi dan aktivitas sel serta pembentukan matriks ekstraselular dan faktor pertumbuhan sehingga penyembuhan luka menjadi lebih lama (Boateng et al., 2008). Sehingga penyerapan cairan eksudat oleh hidrogel memungkinkan untuk mempercepat penyembuhan luka.

Pada fase hemostasis, kandungan jatrophine dalam getah jarak cina dapat meningkatkan jumlah trombosit. Trombosit akan mengeluarkan adenosine difosfat (ADP) yang menyebabkan permukaan trombosit melekat pada lapisan trombosit yang pertama. Trombosit yang baru melekat mengeluarkan lebih banyak ADP, sehingga bertambah jumlah trombosit yang melekat. Proses penumpukan trombosit didukung oleh tromboksan $\mathrm{A}_{2}$ yang secara langsung mendorong agregasi trombosit sehingga dapat mempercepat pembekuan darah dengan cara mengeluarkan lebih banyak ADP (Syarfati dan Damhoeri, 2011). Fibrinogen yang terdapat dalam eksudat memicu koagulasi. Benang fibrin membentuk bekuan yang kemudian akan mengering membentuk keropeng.

Tabel II. Waktu terbentuk keropeng setelah pemberian sediaan

\begin{tabular}{lcc}
\hline Kelompok & $\begin{array}{c}\text { Rata-rata Waktu Terbentuk Keropeng } \\
(\text { jam }) \pm \text { SD }\end{array}$ & $\mathbf{p}^{*}$ \\
\hline Kontrol & $211,7 \pm 19,7$ & - \\
Basis Hidrogel- Kappa & $127,4 \pm 10,8$ & - \\
Sediaan Hidrogel-Kappa & $92,6 \pm 2,2$ & 0,002 \\
Basis Hidrogel-Iota & $125,8 \pm 3,3$ & - \\
Sediaan Hidrogel-Iota & $116,6 \pm 2,2$ & 0,002 \\
\hline *p= Signifikansi perbedaan waktu terbentuk keropeng dibandingkan kelompok kontrol \\
\multicolumn{2}{c}{ berdasarkan uji statistik Mann-Whitney }
\end{tabular}

Selaras dengan hasil pengamatan waktu kering luka, waktu terbentuk keropeng kelompok yang diberi hidrogel getah jarak cina lebih cepat dibandingkan efek dari basisnya masing-masing dan dibandingkan kelompok kontrol (Tabel II). Pada uji Mann-Whitney menunjukkan waktu terbentuk keropeng pada kedua kelompok hidrogel berbeda bermakna $(\mathrm{p}=0,002)$ dibandingkan kontrol. Waktu terbentuknya keropeng rata-rata pada kelompok sediaan hidrogel-kappa (92,6 jam) lebih cepat dibandingkan kelompok yang diberi sediaan hidrogel-iota $(116,6$ jam $)$ secara bermakna $(p=0,007)$. Hal ini menunjukkan adanya pengaruh dari perbedaan basis polimer yang diberikan.

Terbentuknya keropeng menunjukkan proses penyembuhan luka berlanjut ke fase migrasi. Migrasi melibatkan pergerakan sel epitel dan fibroblas kepada area luka untuk menggantikan jaringan yang rusak. Sel ini beregenerasi dari tepi, tumbuh cepat menutup luka di bawah keropeng disertai dengan penebalan epitel. Fase proliferatif terjadi bersamaan atau segera setelah fase migrasi (mulai hari ketiga). Jaringan granulasi dibentuk dari pertumbuhan pembuluh kapiler dan limfatik pada luka dan kolagen disintesis oleh fibroblas untuk membentuk kulit baru (Boateng et al., 2008). 
Kandungan saponin dalam getah jarak cina dapat memicu pembentukan kolagen (Syarfati dan Damhoeri, 2011). Hal ini terlihat dengan berkurangnya diameter luka setelah pemberian sediaan selama 21 hari. Semua kelompok telah mengalami penyempitan diameter luka dari diameter luka awal yaitu 1,5 $\mathrm{cm}$. Diameter luka kelompok kontrol adalah 0,42 cm, lebih besar dibandingkan kelompok yang diberi sediaan uji. Pada Tabel III, terlihat kedua kelompok uji yang diberi sediaan hidrogel getah jarak cina memberikan efek penyempitan diameter luka yang signifikan $(\mathrm{p}=0,002)$ dibandingkan kelompok kontrol. Pada kelompok sediaan hidrogel-kappa tersisa diameter luka rata-rata 0,02 cm, dan kemudian luka tertutup sempurna pada semua subjek uji pada hari ke-23. Sediaan hidrogel-iota memberikan perubahan diameter luka kurang baik dikarenakan masih terdapat luka rata-rata sebesar $0,20 \mathrm{~cm}$. Diameter luka antara kedua kelompok hidrogel berbeda bermakna dengan nilai $\mathrm{p}=0,008$.

Tabel III. Diameter Luka pada Hari ke-21

\begin{tabular}{lcc}
\hline Kelompok & Rata-rata Diameter Luka $(\mathbf{c m}) \pm$ & p* \\
\hline Kontrol & $0,42 \pm 0,03$ & - \\
Basis Hidrogel- Kappa & $0,10 \pm 0,13$ & - \\
Sediaan Hidrogel-Kappa & $0,02 \pm 0,03$ & 0,002 \\
Basis Hidrogel-Iota & $0,09 \pm 0,05$ & - \\
Sediaan Hidrogel-Iota & $0,20 \pm 0,06$ & 0,002 \\
\hline *p=: Signifikansi perbedaan diameter luka dibandingkan kelompok kontrol berdasarkan uji statistik \\
\multicolumn{2}{l}{ Mann-Whitney }
\end{tabular}

Proses penyembuhan luka kelompok kontrol, kelompok hidrogel-kappa dan kelompok hidrogeliota selama 4 minggu terlihat dari Gambar 2, 3, dan 4.

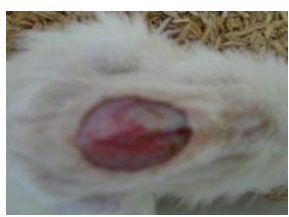

(a)

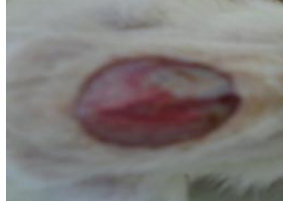

(b)

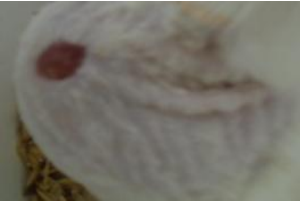

(c)

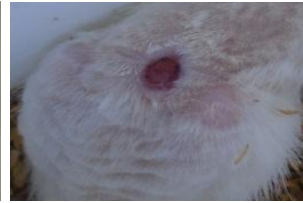

(d)

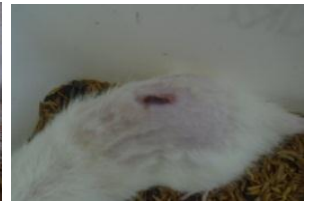

(e)

Gambar 2. Proses penyembuhan luka tikus kelompok kontrol $\begin{array}{llll}\text { (a). Hari ke } 1 \text { (b). Hari ke } 3 \text { (c). Hari ke } 8 \text { (d). Hari ke } 15 & \text { (e). Hari ke } 27\end{array}$

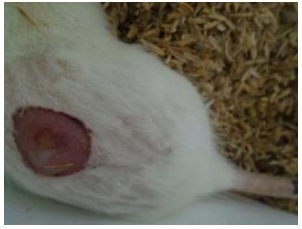

(a)

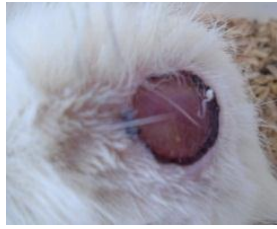

(b)

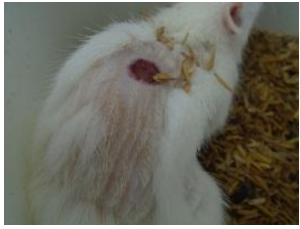

(c)

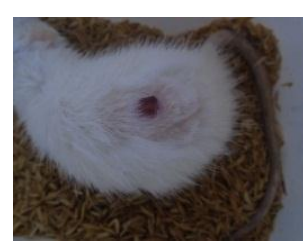

(d)

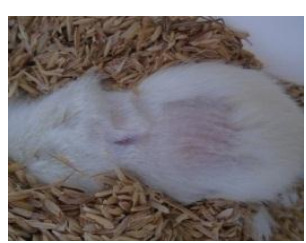

(e)

Gambar 3. Proses penyembuhan luka tikus kelompok hidrogel-kappa

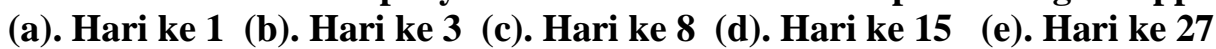

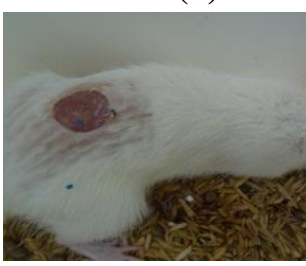

(a)

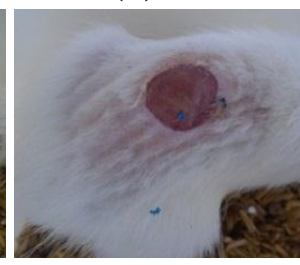

(b)

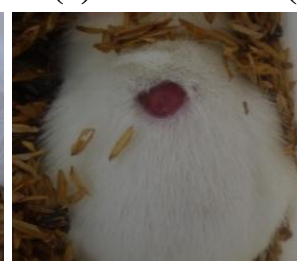

(c)

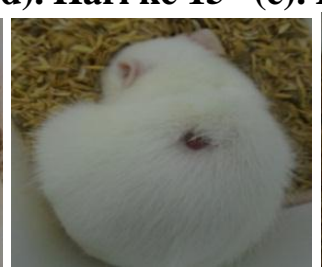

(d)

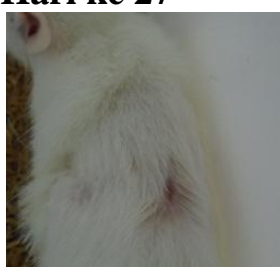

(e)

Gambar 4. Proses penyembuhan luka tikus kelompok hidrogel-iota

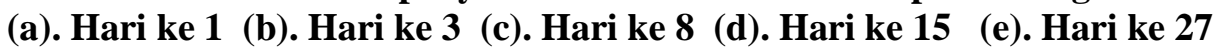

Secara keseluruhan berdasarkan nilai rata-rata pada semua parameter yang diamati, kedua jenis sediaan hidrogel yang mengandung getah jarak cina memberikan efek mempercepat penyembuhan luka. Efek sediaan hidrogel getah jarak cina berbasis karagenan kappa lebih baik dibandingkan sediaan hidrogel berbasis karagenan iota. 


\section{KESIMPULAN}

Sediaan hidrogel mengandung 3\% getah jarak cina dengan basis $2 \%$ karagenan kappa memberikan waktu penyembuhan luka lebih cepat dibandingkan kelompok kontrol secara signifikan $(\mathrm{p}<0,05)$ dan dibandingkan sediaan hidrogel berbasis karagenan iota berdasarkan rata-rata waktu kering luka $(16,6 \pm 2,2$ jam), waktu terbentuk keropeng $(92,6 \pm 2,2$ jam) dan diameter luka pada hari ke-21 (mengecil hingga $0,02 \pm 0,03 \mathrm{~cm})$

\section{UCAPAN TERIMAKASIH}

Terimakasih kepada Lembaga Penelitian dan Pengabdian Masyarakat Universitas Islam Bandung (LPPM UNISBA) yang telah membiayai penelitian ini.

\section{DAFTAR PUSTAKA}

Ahmed, E.M., 2015, Hydrogel: Preparation, characterization, and applications: a review, J Adv Res. 6 (2), $105-121$

Aiyelaagbe,O.O., Oguntuase, B.J., Arimah, B.D., Adeniyi, B.A, 2008, The antimicrobial activity of Jatropha multifida extracts and chromatographic fractions against sexuality transmitted infection. J. Med.Sci, 8(2): 143-147.

Amila, Lestari, F., Rahman, A, 2015, Formulation of Jatropha multifida Linn. latex as topical dosage form and wound healing study in swiss webster mice, in Proceeding International Conference ICB Pharma, Muhammadiyah University of Surakarta, Solo, 8-15.

Boateng, J.S., Matthews, K.R., Stevens H.N.E., Eccleston, G.M, 2008, Wound healing dressings and drug delivery systems: A Review, J Pharm Sci. 97: 2892-2923.

Dougnon, T.V., Klotoé,J.R., Sègbo,J., Atègbo,J., Edorh,A.P., Gbaguidi,F., Hounkpatin,A.S., Dandjesso,C., Fah,L., Fanou, B., Dramane,K., and Loko,F, 2012, Evaluation of The Phytochemical and Hemostatic Potential of Jatropha multifida Sap, Afr J Pharm Pharacol. 6(26): 1943-1948.

Gadri, A., Mulyanti.D, Aprilianti,S., 2014, Formulasi sediaan pembalut luka hidrogel berbasis iotakaragenan dengan metode Freezing and Thawing Cycle, dalam Prosiding Seminar Nasional Penelitian dan PKM Sains, Teknologi dan Kesehatan, LPPM Universitas Islam Bandung, 163170.

Gadri, A., Lestari, F., Dharma, G.C.E., Kartika, R., Shafira, U., 2015, Formulasi pembalut luka hidrogel serbuk getah jarak cina (Jatropha multifida Linn.) berbasis kappa karagenan, dalam Prosiding Seminar Nasional Penelitian dan PKM Kesehatan, LPPM Universitas Islam Bandung, 331-338.

Omidian, H., Park, K. 2010, Biomedical applications of hydrogels handbook. Springer Science. USA. 23,351 .

Schwartz, S.I. 2000, Intisari Prinsip-prinsip Ilmu Bedah, terjemahan Laniyati. EGC. Jakarta. 25, 133137.

Syarfati, K. E., Damhoeri,A., 2011, The potential of jarak cina (Jatropha multifida L.) secretion in healing new-wounded mice, Jurnal Natural. 11(1):16-19. 